\title{
Patient Portal Barriers and Group Differences: Cross-Sectional National Survey Study
}

Kea Turner $^{{ }^{*}}$, MPH, MA, PhD; Alecia Clary ${ }^{2 *}, \mathrm{MSW}, \mathrm{PhD}$; Young-Rock Hong ${ }^{3}$, MPH, PhD; Amir Alishahi Tabriz ${ }^{4^{*}}$, MPH, MD, PhD; Christopher M Shea ${ }^{5 *}$, MA, MPA, PhD

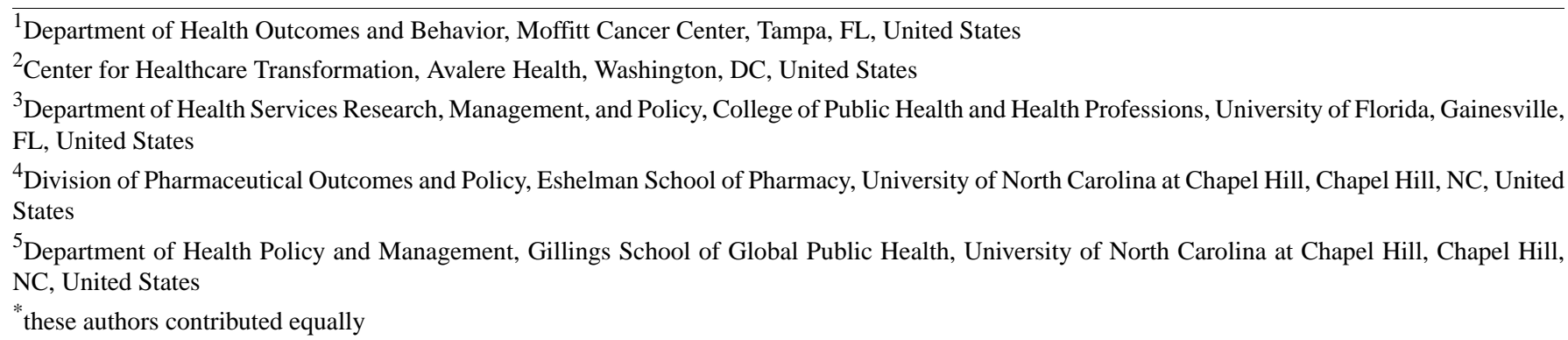

\section{Corresponding Author:}

Kea Turner, MPH, MA, PhD

Department of Health Outcomes and Behavior

Moffitt Cancer Center

12902 USF Magnolia Drive, MRC-CANCONT

Tampa, FL, 33612

United States

Phone: 18137455213

Email: kea.turner@gmail.com

\section{Abstract}

Background: Past studies examining barriers to patient portal adoption have been conducted with a small number of patients and health care settings, limiting generalizability.

Objective: This study had the following two objectives: (1) to assess the prevalence of barriers to patient portal adoption among nonadopters and (2) to examine the association between nonadopter characteristics and reported barriers in a nationally representative sample.

Methods: Data from this study were obtained from the 2019 Health Information National Trends Survey. We calculated descriptive statistics to determine the most prevalent barriers and conducted multiple variable logistic regression analysis to examine which characteristics were associated with the reported barriers.

Results: The sample included 4815 individuals. Among these, 2828 individuals $(58.73 \%)$ had not adopted a patient portal. Among the nonadopters $(n=2828)$, the most prevalent barriers were patient preference for in-person communication $(1810 / 2828$, $64.00 \%)$, no perceived need for the patient portal $(1385 / 2828,48.97 \%)$, and lack of comfort and experience with computers (735/2828, 25.99\%). Less commonly, individuals reported having no patient portal $(650 / 2828,22.98 \%)$, no internet access $(650 / 2828,22.98 \%)$, privacy concerns $(594 / 2828,21.00 \%)$, difficulty logging on $(537 / 2828,18.99 \%)$, and multiple patient portals $(255 / 2828,9.02 \%)$ as barriers. Men had significantly lower odds of indicating a preference for speaking directly to a provider compared with women (odds ratio [OR] 0.75, 95\% CI 0.60-0.94; $P=.01$ ). Older age (OR 1.01, 95\% CI 1.00-1.02; $P<.001$ ), having a chronic condition (OR 1.83, 95\% CI 1.44-2.33; $P<.001$ ), and having an income lower than US $\$ 20,000$ (OR 1.61, 95\% CI $1.11-2.34 ; P=.01$ ) were positively associated with indicating a preference for speaking directly to a provider. Hispanic individuals had significantly higher odds of indicating that they had no need for a patient portal (OR 1.59, 95\% CI $1.24-2.05 ; P<.001)$ compared with non-Hispanic individuals. Older individuals (OR 1.05, 95\% CI 1.04-1.06; $P<.001$ ), individuals with less than a high school diploma (OR 3.15, 95\% CI 1.79-5.53; $P<.001$ ), and individuals with a household income of less than US $\$ 20,000$ (OR 2.78, 95\% CI 1.88-4.11; $P<.001$ ) had significantly higher odds of indicating that they were uncomfortable with a computer.

Conclusions: The most common barriers to patient portal adoption are preference for in-person communication, not having a need for the patient portal, and feeling uncomfortable with computers, which are barriers that are modifiable and can be intervened 
upon. Patient characteristics can help predict which patients are most likely to experience certain barriers to patient portal adoption. Further research is needed to tailor implementation approaches based on patients' needs and preferences.

(J Med Internet Res 2020;22(9):e18870) doi: 10.2196/18870

\section{KEYWORDS}

patient portal; personal health record; electronic health record; implementation

\section{Introduction}

Patient portals have demonstrated promise in improving patient engagement and outcomes [1-7] but remain underutilized [8-13]. Patient portals (web applications tethered to the electronic health record $[E H R]$ ) offer patients numerous ways to better engage in their own care, such as viewing and downloading health information and securely messaging their health care providers [14-16]. To encourage patient portal use among patients and providers, the US government has taken steps to promote patient portal adoption [17,18]. Stage 2 of the Meaningful Use EHR Incentive Program, which is now part of the Merit-based Incentive Payment Program, requires eligible providers to ensure that a certain percentage of patients are downloading and viewing health information and securely messaging their care team $[17,19]$. Eligible hospitals are also required to ensure that patients download and view health information under the Promoting Interoperability for Hospitals Program. Additionally, the 21st Century Cures Act encourages providers to offer access to patient portals through digital health applications in order to enhance a patient's ability to maintain a longitudinal health record (ie, integrate portal data from multiple providers) and to share the record with other health care providers [18]. Despite these policy initiatives, patient portal adoption has been slow.

Studies have consistently shown that patient portal usage has increased over time but remains low overall [10,20,21]. A recent nationally representative study (weighted $n=254,183$ individuals) found a significant increase in the adoption of patient portals in the United States, from $12.5 \%$ in 2011 to $25.0 \%$ in 2017 $(P<.001)$ [10]. However, an overall adoption rate of $25 \%$ is modest and means that many patients are still not using patient portals. To increase adoption, some health care systems have started offering access to patient portals through smartphone apps [22]. Smartphone app access allows patients to integrate data from multiple patient portals and may increase access for patients who do not have access to a home computer. However, a recent study examining patient portal access through a smartphone app found that the rate of new users did not significantly change over time $(P=.18)$ and that the proportion of patient portal adopters who logged into the smartphone app was low (population mean [] 0.7\%, SD 0.2\%-2.1\%) [23]. This finding suggests that there are other barriers that are affecting patient portal adoption and that additional implementation strategies, beyond accessibility through smartphone apps, may be needed to enhance adoption.

Several studies have identified patient- and provider-level barriers that are associated with low adoption of patient portals. Studies have consistently shown that lower socioeconomic status, older age, rural residence, male gender, black race, Hispanic ethnicity, and public or no insurance are associated with lower adoption of patient portals [8,24-30]. On the other hand, patients with a usual source of care, those having better patient-provider communication, and those with multiple chronic conditions are more likely to adopt patient portals [29,31,32]. Studies have also enumerated many barriers to adoption, such as computer literacy, lack of internet access, privacy concerns, difficulty logging in, and presence of different portals for different providers [33-43]. Many of these studies, however, involved small samples, limiting the ability to discern which barriers are most prominent and which patient subgroups are most likely to experience a specific barrier.

To address this gap, this study had the following two objectives: (1) to assess the prevalence of barriers to patient portal adoption among nonadopters and (2) to examine the association between nonadopter characteristics and reported barriers in a nationally representative sample. By clarifying which barriers are most common and which patient subgroups are most affected by these barriers, future studies can develop targeted implementation approaches to advance patient portal adoption.

\section{Methods}

\section{Study Design}

This was a cross-sectional observational study conducted in 2019. The unit of analysis was the individual.

\section{Data}

Data for this study were obtained from the Health Information National Trends Survey (HINTS), which is administered by the National Cancer Institute (NCI). The HINTS collects data on individuals' use of and access to health-related information, and health-related knowledge, awareness, and behaviors. The sampling frame included all civilian noninstitutionalized adults (aged over 18 years) living in the United States, and it was considered a nationally representative sample. The sampling strategy was two-staged. First, a stratified sample was selected based on a file of residential addresses maintained by the NCI, and then, one adult within each selected household was sampled. The HINTS 5, Cycle 3 survey, which was used for this study, was administered from January through April 2019 via a paper-based survey and an experimental web survey. The overall response rate was $30.3 \%$.

\section{Study Population}

The HINTS 5, Cycle 3 sample included 5438 individuals. We removed individuals with missing data for key variables (eg, complete case analysis) since the rate of missingness was less than $7 \%$ for study variables. We examined whether individuals with missing data were more likely to report nonadoption of patient portals and did not find a relationship; therefore, we concluded that the data were missing at random. We excluded 
individuals who reported not visiting a health care provider in the past 12 months $(n=542)$. After removing individuals with missing data and individuals who had not visited a provider in the past 12 months, the analytic sample included 4815 individuals (weighted $n=227,463,350$ ).

\section{Measures}

\section{Adoption of Patient Portals}

We divided the sample based on adoption and nonadoption of patient portals according to a survey question ("How many times did you access your online medical record in the last 12 months?"). Individuals selecting zero times were categorized as "nonadopters" and individuals selecting one or more times were categorized as "adopters."

\section{Barriers to Patient Portal Adoption}

The survey asked a series of yes/no questions eliciting reasons why patients have not adopted patient portals, including patient preference to speak to a health care provider directly, lack of internet access, concerns about privacy, lack of patient portals, trouble remembering passwords, lack of experience with computers, and having more than one patient portal. Participants were allowed to select more than one barrier. Each of these barriers was categorized as a binary variable.

\section{Individual Characteristics}

The survey captured several measures of patient characteristics. We included characteristics associated with patient portal adoption that have been reported in previous studies [8,24-30], including binary measures of gender, black race, Hispanic ethnicity, marital status, insurance status, rural residence, presence of a chronic condition (eg, diabetes, hypertension, and heart disease), and having a regular provider. We included age as a continuously measured variable. We also included three categorical variables, including income (eg, less than US $\$ 20,000$, US $\$ 20,000-\$ 34,999$, US $\$ 35,000-\$ 49,999$, US $\$ 50,000-\$ 74,999$, and US $\$ 75,000$ or more), education (eg, less than high school diploma, high school diploma, college degree, and postgraduate degree), and satisfaction with care (eg, excellent, very good, good, fair, and poor). Each of these variables has been shown to be a predictor of patient portal adoption in previous research [8,24-30].

\section{Analytic Approach}

First, we described the characteristics of the study population, conducting bivariate analyses to compare the characteristics of the adopters and nonadopters of patient portals. Second, we adopted a series of multiple logistic regression models to examine which characteristics were associated with barriers that were experienced by at least $10 \%$ of participants. We chose $10 \%$ as a cutoff to ensure that we had an adequate sample size for each logistic regression. We present the results for the three most common barriers in the Results section and provide the results for the less common barriers in Multimedia Appendix 1 and Multimedia Appendix 2. The statistical analyses were conducted using Stata (version 16; StataCorp). We used jackknife replicate weights to account for the complex survey design (ie, stratified cluster sample) in the variance calculations. We also applied sampling weights to develop nationally representative estimates. We adhered to the guidelines for weighting and variance estimation from the NCI [44]. To ensure adequate reporting of our study, we followed the Strengthening the Reporting of Observational Studies in Epidemiology (STROBE) statement [45]. This study was exempted by the Advarra Institutional Review Board owing to the use of publicly available data.

\section{Results}

\section{Sample Characteristics}

The sample included 4815 individuals (weighted $\mathrm{n}=227,463,350)$. The majority of participants were female $(2746 / 4815,57.03 \%)$, white $(3755 / 4815,77.99 \%)$, and non-Hispanic $(4024 / 4815,83.57 \%)$ (Table 1). The mean age was 56.3 years (SD 16.7 years). Less than half of the participants had a college degree $(1307 / 4815,27.14 \%)$ or postgraduate degree $(963 / 4815,20.00 \%)$ and a household income of US $\$ 75,000$ or more per year $(1719 / 4815,35.70 \%)$.

There were more individuals who had not adopted a patient portal (ie, nonadopters; 2828/4815, 58.73\%) than individuals who had adopted a patient portal (ie, adopters; 1987/4815, $41.27 \%$ ) (Table 1). Nonadopters were significantly more likely to be male $(P<.001)$, be of black race $(P=.001)$, have Hispanic ethnicity $(P=.02)$, have lower education attainment $(P<.001)$, and have lower income $(P<.001)$. Nonadopters were also significantly more likely to live in a rural area $(P=.002)$, be unmarried $(P=.001)$, be uninsured $(P=.001)$, not have a usual source of care $(P<.001)$, and rate their quality of care lower $(P<.001)$ compared with adopters. Age and having a chronic condition did not significantly impact the decision to adopt a patient portal. 
Table 1. Sample characteristics.

\begin{tabular}{|c|c|c|c|c|}
\hline Characteristic & $\begin{array}{l}\text { Total population }(\mathrm{N}=4815 \text {; } \\
\text { weighted: } 227,463,350)\end{array}$ & $\begin{array}{l}\text { Adopters }(\mathrm{N}=1987 \text {; weight- } \\
\text { ed: } 90,644,145)\end{array}$ & $\begin{array}{l}\text { Nonadopters }(\mathrm{N}=2828 \text {; } \\
\text { weighted: } 136,800,000)\end{array}$ & $P$ value \\
\hline Gender, n (\%) & & & & $<.001$ \\
\hline Male & $2069(42.97 \%)$ & $781(39.31 \%)$ & $1288(45.54 \%)$ & \\
\hline Female & $2746(57.03 \%)$ & $1206(60.69 \%)$ & $1540(54.46 \%)$ & \\
\hline Race, n (\%) & & & & .001 \\
\hline Black & $772(16.03 \%)$ & $255(12.83 \%)$ & $517(18.28 \%)$ & \\
\hline White & $3755(77.99 \%)$ & $1649(82.99 \%)$ & $2106(74.47 \%)$ & \\
\hline Ethnicity, n (\%) & & & & .02 \\
\hline Hispanic & $791(16.43 \%)$ & $265(13.34 \%)$ & $526(18.60 \%)$ & \\
\hline Non-Hispanic & $4024(83.57 \%)$ & $1722(86.66 \%)$ & $2302(81.40 \%)$ & \\
\hline Age, $\mu^{\mathrm{a}}(\mathrm{SD})$ & $56.3(16.79)$ & $54.1(16.01)$ & $57.8(17.03)$ & .08 \\
\hline Education, $\mathbf{n}(\%)$ & & & & $<.001$ \\
\hline Less than $H S^{b}$ & $280(5.82 \%)$ & $28(1.41 \%)$ & $252(8.91 \%)$ & \\
\hline HS diploma & $2265(47.04 \%)$ & $739(37.19 \%)$ & $1526(53.96 \%)$ & \\
\hline College degree & $1307(27.14 \%)$ & $651(32.76 \%)$ & $656(23.20 \%)$ & \\
\hline Postgraduate degree & $963(20.00 \%)$ & $569(28.64 \%)$ & $394(13.93 \%)$ & \\
\hline Income, n (\%) & & & & $<.001$ \\
\hline Less than US $\$ 20,000$ & $762(15.83 \%)$ & $154(7.75 \%)$ & $608(21.50 \%)$ & \\
\hline US $\$ 20,000$ to $\$ 34,999$ & $547(11.36 \%)$ & $164(8.25 \%)$ & $383(13.54 \%)$ & \\
\hline US $\$ 35,000$ to $\$ 49,999$ & $575(11.94 \%)$ & $233(11.73 \%)$ & $342(12.09 \%)$ & \\
\hline US $\$ 50,000$ to $\$ 74,999$ & $786(16.32 \%)$ & $363(18.27 \%)$ & $423(14.96 \%)$ & \\
\hline US $\$ 75,000$ or more & $1719(35.70 \%)$ & $929(46.75 \%)$ & $790(27.93 \%)$ & \\
\hline Rural, n (\%) & & & & .002 \\
\hline Yes & $521(10.82 \%)$ & $169(8.51 \%)$ & $352(12.48 \%)$ & \\
\hline No & $4294(89.18 \%)$ & $1818(91.49 \%)$ & $2476(87.55 \%)$ & \\
\hline Marital status, n (\%) & & & & .001 \\
\hline Married & $2656(55.16 \%)$ & $1258(63.31 \%)$ & $1398(49.43 \%)$ & \\
\hline Unmarried & $2159(44.84 \%)$ & $729(36.69 \%)$ & $1430(50.57 \%)$ & \\
\hline Chronic condition, n (\%) & & & & .06 \\
\hline Yes & $2633(54.68 \%)$ & $1051(52.89 \%)$ & $1582(55.94 \%)$ & \\
\hline No & $2182(45.32 \%)$ & $936(47.11 \%)$ & $1246(44.06 \%)$ & \\
\hline Insurance status, n (\%) & & & & .001 \\
\hline Insured & $4559(94.68 \%)$ & $1941(97.68 \%)$ & $2618(92.57 \%)$ & \\
\hline Uninsured & $256(5.32 \%)$ & $46(2.32 \%)$ & $210(7.42 \%)$ & \\
\hline Regular provider, n (\%) & & & & $<.001$ \\
\hline Yes & $3392(70.45 \%)$ & $1614(81.23 \%)$ & $1778(62.87 \%)$ & \\
\hline No & $1423(29.55 \%)$ & $373(18.77)$ & $1050(37.13 \%)$ & \\
\hline Quality of care, $n(\%)$ & & & & $<.001$ \\
\hline Excellent & $1829(37.99 \%)$ & $764(38.45 \%)$ & $1065(37.66 \%)$ & \\
\hline Very good & $1806(37.51 \%)$ & $797(40.11 \%)$ & $1009(35.68 \%)$ & \\
\hline Good & $862(17.90 \%)$ & $344(17.31 \%)$ & $518(18.32 \%)$ & \\
\hline Fair & $197(4.91 \%)$ & $70(3.52 \%)$ & $127(4.49 \%)$ & \\
\hline
\end{tabular}




\begin{tabular}{clll}
\hline Characteristic & $\begin{array}{l}\text { Total population }(\mathrm{N}=4815 ; \\
\text { weighted: } 227,463,350)\end{array}$ & $\begin{array}{l}\text { Adopters }(\mathrm{N}=1987 ; \text { weight- } \\
\text { ed: } 90,644,145)\end{array}$ & $\begin{array}{l}\text { Nonadopters }(\mathrm{N}=2828 ; \\
\text { weighted: } 136,800,000)\end{array}$ \\
\hline Poor & $120(2.49 \%)$ & $12(0.60 \%)$ & $108(3.82 \%)$ \\
\hline
\end{tabular}

${ }^{\mathrm{a}} \mu$ : population mean.

${ }^{\mathrm{b}} \mathrm{HS}$ : high school

\section{Prevalence of Barriers to Patient Portal Adoption Among Nonadopters}

Among nonadopters $(n=2828)$, the most prevalent barrier to patient portal adoption was patient preference for in-person communication $(1810 / 2828,64.00 \%)$ (Table 2). The second most common barrier was no perceived need for the patient portal $(1385 / 2828,48.97 \%)$. The third most common barrier was lack of comfort and experience with computers (735/2828, $25.99 \%$ ). Less commonly, individuals reported having no patient portal $(650 / 2828,22.98 \%)$, no internet access $(650 / 2828$, $22.98 \%$ ), privacy concerns $(594 / 2828,21.00 \%)$, difficulty logging on $(537 / 2828,18.99 \%)$, and multiple patient portals $(255 / 2828,9.02 \%)$ (Multimedia Appendix 1 and Multimedia Appendix 2).

\section{Nonadopter Characteristics and Barriers to Patient Portal Adoption}

For the first barrier, men had significantly lower odds of indicating a preference for speaking directly to a provider compared with women (odds ratio [OR] 0.75, 95\% CI 0.60-0.94; $P=.01$ ) (Table 2). Conversely, older age (OR 1.01, 95\% CI $1.00-1.02 ; P<.001)$, having a chronic condition (OR $1.83,95 \%$ CI 1.44-2.33; $P<.001$ ), having a regular provider (OR 1.45, 95\% CI 1.14-1.84; $P=.003)$, and having an income lower than US $\$ 20,000$ (OR $1.61,95 \%$ CI $1.11-2.34 ; P=.01$ ) were positively associated with indicating a preference for speaking directly to a provider. In terms of education, individuals with less than a high school education (OR 2.03, 95\% CI 1.17-3.50; $P=.011$ ), a high school diploma (OR 2.16, 95\% CI 1.57-2.97; $P<.001$ ), and a college degree (OR 1.40, 95\% CI 1.01-1.94; $P=.04$ ) had significantly higher odds of preferring to speak directly to a provider compared with individuals having a postgraduate degree. Individuals who rated their quality of care as "very good" (OR $0.58,95 \%$ CI $0.36-0.95 ; P=.03$ ) or "good" (OR 0.64,
95\% CI $0.47-0.87 ; P=.004$ ) had significantly lower odds of preferring to speak directly to a provider compared with individuals who rated their quality of care as "poor."

For the second barrier, Hispanic individuals had significantly higher odds of indicating that they had no need for a patient portal (OR 1.59, 95\% CI 1.24-2.05; $P<.001$ ) compared with non-Hispanic individuals (Table 2). In contrast, older individuals (OR 0.99, 95\% CI 0.99-1.00; $P=.04$ ), individuals who rated their quality of care as "excellent" (OR $0.33,95 \%$ CI 0.12-0.88; $P=.03$ ), and individuals with a household income of US $\$ 20,000$ to $\$ 34,999$ (OR $0.61,95 \%$ CI $0.44-0.85 ; P=.003$ ) or less than US \$20,000 (OR 0.68, 95\% CI 0.50-0.93; $P=.02$ ) had significantly lower odds of indicating that they had no need for a patient portal.

For the third barrier, older individuals (OR 1.05, 95\% CI $1.04-1.06 ; P<.001)$, individuals with a chronic condition (OR $1.42,95 \%$ CI 1.08-1.86; $P=.01)$, and individuals who rated their quality of care as "good" (OR 1.55, 95\% CI 1.11-2.15; $P=.009)$ had significantly higher odds of indicating that they were uncomfortable with a computer (Table 2). Individuals with less than a high school diploma (OR 3.15, 95\% CI 1.79-5.53; $P<.001)$ and a high school diploma (OR 2.79, 95\% CI 1.80-4.33; $P<.001)$ had significantly higher odds of indicating that they were uncomfortable with a computer. Individuals with a household income of less than US $\$ 20,000$ (OR 2.78, 95\% CI $1.88-4.11 ; P<.001$ ), US $\$ 20,000$ to $\$ 34,999$ (OR $2.17,95 \%$ CI $1.45-3.27 ; P<.001$ ), US $\$ 35,000$ to $\$ 49,999$ (OR $1.94,95 \%$ CI $1.30-2.90 ; P=.001$ ), and US $\$ 50,000$ to $\$ 74,999$ (OR $1.57,95 \%$ CI 1.30-2.90; $P=.001$ ) had significantly higher odds of indicating that they were uncomfortable with a computer compared with individuals having a household income of US $\$ 75,000$ or more. Black individuals (OR 0.93, 95\% CI 0.89-0.98; $P=.007$ ) were less likely to indicate that they were uncomfortable with a computer compared with white individuals. 
Table 2. Nonadopter characteristics and the three most common barriers to patient portal adoption.

\begin{tabular}{|c|c|c|c|c|c|c|c|c|c|}
\hline \multirow[t]{2}{*}{ Characteristic } & \multicolumn{3}{|c|}{$\begin{array}{l}\text { Model 1: Speaking directly to a } \\
\text { provider }(\mathrm{N}=1926 \text {; weighted: } \\
88,630,105)\end{array}$} & \multicolumn{3}{|c|}{$\begin{array}{l}\text { Model 2: No need for a patient portal } \\
(\mathrm{N}=1893 \text {; weighted: } 87,531,372)\end{array}$} & \multicolumn{3}{|c|}{$\begin{array}{l}\text { Model 3: Uncomfortable with a com- } \\
\text { puter }(\mathrm{N}=1893 \text {; weighted: } \\
87,531,372)\end{array}$} \\
\hline & $\mathrm{OR}^{\mathrm{a}}$ & $95 \% \mathrm{CI}$ & $P$ value & OR & $95 \% \mathrm{CI}$ & $P$ value & OR & $95 \% \mathrm{CI}$ & $P$ value \\
\hline \multicolumn{10}{|l|}{ Gender } \\
\hline Male & 0.75 & $0.60-0.94$ & .01 & 1.03 & $0.85-1.25$ & .75 & 1.18 & $0.93-1.49$ & .18 \\
\hline Female $\left(\right.$ ref $\left.^{b}\right)$ & N/A ${ }^{c}$ & N/A & N/A & N/A & N/A & N/A & N/A & N/A & N/A \\
\hline \multicolumn{10}{|l|}{ Race } \\
\hline Black & 1.01 & $0.96-1.06$ & .73 & 1.05 & $1.00-1.10$ & .05 & 0.93 & $0.89-0.98$ & .007 \\
\hline White (ref) & N/A & N/A & N/A & N/A & N/A & N/A & $\mathrm{N} / \mathrm{A}$ & $\mathrm{N} / \mathrm{A}$ & $\mathrm{N} / \mathrm{A}$ \\
\hline \multicolumn{10}{|l|}{ Ethnicity } \\
\hline Hispanic & 0.90 & $0.67-1.21$ & .48 & 1.59 & $1.24-2.05$ & $<.001$ & 0.81 & $0.60-1.10$ & .19 \\
\hline Non-Hispanic (ref) & N/A & N/A & N/A & N/A & N/A & N/A & N/A & N/A & N/A \\
\hline Age & 1.01 & $1.00-1.02$ & $<.001$ & 0.99 & $0.99-1.00$ & .04 & 1.05 & $1.04-1.06$ & $<.001$ \\
\hline \multicolumn{10}{|l|}{ Education } \\
\hline Less than $\mathrm{HS}^{\mathrm{d}}$ & 2.03 & $1.17-3.50$ & .01 & 0.68 & $0.43-1.07$ & .10 & 3.15 & $1.79-5.53$ & $<.001$ \\
\hline HS diploma & 2.16 & $1.57-2.97$ & $<.001$ & 0.98 & $0.73-1.32$ & .91 & 2.79 & $1.80-4.33$ & $<.001$ \\
\hline College degree & 1.40 & $1.01-1.94$ & .04 & 1.1 & $0.81-1.50$ & .55 & 1.39 & $0.86-2.26$ & .18 \\
\hline Postgraduate (ref) & N/A & N/A & N/A & N/A & N/A & N/A & N/A & N/A & N/A \\
\hline \multicolumn{10}{|l|}{ Income } \\
\hline Less than US $\$ 20,000$ & 1.61 & $1.11-2.34$ & .01 & 0.68 & $0.50-0.93$ & .02 & 2.78 & $1.88-4.11$ & $<.001$ \\
\hline US $\$ 20,000$ to $\$ 34,999$ & 1.32 & $0.90-1.94$ & .16 & 0.61 & $0.44-0.85$ & .003 & 2.17 & $1.45-3.27$ & $<.001$ \\
\hline US $\$ 35,000$ to $\$ 49,999$ & 0.97 & $0.68-1.38$ & .86 & 0.79 & $0.58-1.08$ & .14 & 1.94 & $1.30-2.90$ & $<.001$ \\
\hline US $\$ 50,000$ to $\$ 74,999$ & 1.19 & $0.86-1.64$ & .29 & 0.99 & $0.74-1.32$ & .92 & 1.57 & $1.06-2.31$ & .02 \\
\hline $\begin{array}{l}\text { US } \$ 75,000 \text { or more } \\
\text { (ref) }\end{array}$ & N/A & $\mathrm{N} / \mathrm{A}$ & $\mathrm{N} / \mathrm{A}$ & N/A & N/A & $\mathrm{N} / \mathrm{A}$ & N/A & $\mathrm{N} / \mathrm{A}$ & $\mathrm{N} / \mathrm{A}$ \\
\hline \multicolumn{10}{|l|}{ Rural } \\
\hline Yes & 1.05 & $0.74-1.49$ & .78 & 1.06 & $0.79-1.42$ & .70 & 1.02 & $0.72-1.45$ & .91 \\
\hline No (ref) & N/A & N/A & N/A & N/A & N/A & N/A & N/A & N/A & N/A \\
\hline \multicolumn{10}{|l|}{ Marital status } \\
\hline Married & 1.04 & $0.82-1.32$ & .74 & 0.86 & $0.69-1.06$ & .16 & 1.20 & $0.93-1.56$ & .16 \\
\hline Unmarried (ref) & N/A & N/A & N/A & N/A & N/A & N/A & N/A & N/A & N/A \\
\hline \multicolumn{10}{|l|}{ Chronic condition } \\
\hline Yes & 1.83 & $1.44-2.33$ & $<.001$ & 0.93 & $0.75-1.16$ & .53 & 1.42 & $1.08-1.86$ & .01 \\
\hline No (ref) & N/A & $\mathrm{N} / \mathrm{A}$ & N/A & N/A & N/A & N/A & N/A & $\mathrm{N} / \mathrm{A}$ & N/A \\
\hline \multicolumn{10}{|l|}{ Insurance status } \\
\hline Uninsured & 0.88 & $0.53-1.47$ & .63 & 0.85 & $0.53-1.35$ & .49 & 0.60 & $0.31-1.15$ & .12 \\
\hline Insured (ref) & N/A & N/A & N/A & N/A & N/A & N/A & N/A & $\mathrm{N} / \mathrm{A}$ & N/A \\
\hline \multicolumn{10}{|l|}{ Regular provider } \\
\hline Yes & 1.45 & $1.14-1.84$ & .003 & 1.19 & $0.96-1.48$ & .12 & .98 & $0.75-1.30$ & .92 \\
\hline No (ref) & N/A & N/A & N/A & N/A & N/A & N/A & N/A & N/A & N/A \\
\hline \multicolumn{10}{|l|}{ Quality of care } \\
\hline Excellent & 0.52 & $0.19-1.42$ & .20 & 0.33 & $0.12-0.88$ & .03 & 1.76 & $0.62-4.99$ & .29 \\
\hline
\end{tabular}




\begin{tabular}{|c|c|c|c|c|c|c|c|c|c|}
\hline \multirow[t]{2}{*}{ Characteristic } & \multicolumn{3}{|c|}{$\begin{array}{l}\text { Model 1: Speaking directly to a } \\
\text { provider (N=1926; weighted: } \\
88,630,105)\end{array}$} & \multicolumn{3}{|c|}{$\begin{array}{l}\text { Model 2: No need for a patient portal } \\
\text { (N=1893; weighted: } 87,531,372)\end{array}$} & \multicolumn{3}{|c|}{$\begin{array}{l}\text { Model 3: Uncomfortable with a com- } \\
\text { puter }(\mathrm{N}=1893 \text {; weighted: } \\
87,531,372)\end{array}$} \\
\hline & $\mathrm{OR}^{\mathrm{a}}$ & $95 \% \mathrm{CI}$ & $P$ value & OR & $95 \% \mathrm{CI}$ & $P$ value & OR & $95 \% \mathrm{CI}$ & $P$ value \\
\hline Very good & 0.58 & $0.36-0.95$ & .03 & 0.69 & $0.44-1.08$ & .10 & 1.41 & $0.83-2.39$ & .21 \\
\hline Good & 0.64 & $0.47-0.87$ & .004 & 0.92 & $0.71-1.20$ & .54 & 1.55 & $1.11-2.15$ & .009 \\
\hline Fair & 0.93 & $0.71-1.22$ & .60 & 0.99 & $0.79-1.24$ & .94 & 1.09 & $0.82-1.46$ & .54 \\
\hline Poor (ref) & N/A & N/A & N/A & N/A & N/A & N/A & N/A & N/A & N/A \\
\hline Constant & 0.66 & $0.32-1.36$ & .26 & 0.94 & $0.50-1.77$ & .86 & 0.01 & $0.00-0.01$ & $<.001$ \\
\hline
\end{tabular}

${ }^{\mathrm{a} O R}$ : odds ratio.

${ }^{b}$ ref: reference.

${ }^{\mathrm{c}} \mathrm{N} / \mathrm{A}$ : not applicable.

${ }^{\mathrm{d}}$ HS: high school.

\section{Discussion}

\section{Principal Findings}

The goal of this study was to assess the prevalence of barriers to patient portal adoption in a nationally representative sample and to understand which patient subgroups are most likely to experience a given barrier. Our study found that the most common barriers to patient portal adoption are an individual's preference to speak to a provider in person, not having a need for the patient portal, and feeling uncomfortable with computers, which are barriers that are modifiable and can be intervened upon. Less frequently, patients reported concerns with privacy, internet access, difficulty logging on, and having multiple patient portals. Our study identified that patient characteristics can help predict which patients are most likely to experience certain barriers to patient portal adoption. Older adults and women, for example, commonly reported preference for in-person communication as a barrier to patient portals. We discuss implications for policy and practice below.

Consistent with previous studies, our study indicated that patient preference for in-person communication with providers serves as a barrier to patient portal adoption [38,46-49]. This study extends prior studies by demonstrating that this barrier may be more common $(1810 / 2828,64.00 \%)$ than previously thought and that certain patient demographics are associated with preferring in-person communication (eg, women, older patients, and patients with lower income and education). Dissemination strategies, which target information to a specific audience, may be needed to demonstrate that patient portals are meant to complement rather than replace in-person communication with providers [50]. For developing better messaging, however, there is a need for more implementation studies identifying effective practices for using the patient portal as a means to bolster patient-physician communication during visits. There have been successful examples of this, including collecting and displaying patient-reported outcomes through the portal, and using the portal to facilitate advanced care planning discussions [12,38,51-53]. These strategies should be replicated in additional settings.

Almost half of the individuals in our study indicated that not having a need for a patient portal was a barrier to adoption, which has emerged as a barrier in past research [33,34,36,37]. Our study found that Hispanic and younger individuals were more likely to not see a need for the patient portal. A prior study recommended using real-life patient stories that demonstrate how a patient portal can be used to make the case for why a patient portal might be valuable [54]. There also remains a need to do more usability testing with patient portals and apply user-centered design approaches to better understand what features within the patient portal would be valuable to patients [55-57]. Studies have identified a number of usability issues, including not having information presented in multiple languages, lack of educational resources, poor data visualization and lack of contextualization for laboratory values, and lack of personalization [58-60]. In response, some systems have tested creative strategies, such as offering tailored patient education, and have used motivational strategies (eg, social comparisons and gamification) to enhance the relevance of the patient portal and ensure that the portal is meeting user needs [55,61]. Future studies are needed to test strategies that align the patient portal with patients' information needs. Some systems have also trained providers on the portal and created time within clinic workflow to show patients what the portal is and how to use it, and these strategies may enhance patients' perceived need for the portal $[62,63]$. Further testing is needed to see whether this is an effective implementation approach.

Our study also found that lack of comfort with computers $(735 / 2828,25.99 \%)$ was a common barrier to patient portal adoption, a finding similar to that in past studies [33-35,37,64-66]. Consistent with prior work, we found that older individuals and individuals with lower income and education attainment were more likely to report lack of comfort with computers as a barrier to patient portal adoption. Several studies have tested strategies, such as having health care systems offer patient portal demonstrations to patients, as means to increase comfort with computers and ultimately patient portal adoption [2,62,67]. Researchers have also recommended providing additional support to older individuals who may lack comfort with computers, such as printed handouts and an option to call a toll free line for additional technical assistance [67,68]. Past studies have found that in-person training can improve eHealth literacy among older adults [69-71]; however, few studies have been performed in clinical settings or have included 
clinical outcomes. Thus, additional research is warranted. Past studies have suggested that some older individuals experience additional barriers to technology adoption, such as vision, cognitive, and dexterity deficits [72]. Future studies should test whether modifications to patient portals, such as larger font size, increased contrast between the text and background, and voice-enabled applications, could increase comfort with patient portals among older frail adults. Some health care systems have also allowed patients to designate a caregiver to access the patient portal on their behalf, although uptake has been slow [73-75]. Implementation strategies that incorporate patient caregivers, such as proxy portal access, training for caregivers on the patient portal, and allowing patients to choose which information is shared with the caregiver, could help make the portal more accessible to patients who lack comfort with technology.

\section{Limitations}

This study has a number of limitations. First, the HINTS does not collect any information at the site of care where a patient is seen. It is possible that system- and provider-level factors influence which patients are most likely to experience certain barriers to patient portal adoption. For example, patients who receive care in a Veterans Affairs hospital may be more likely to report a need for the patient portal since the Veterans Affairs has been an early adopter of patient portals [57]. Additionally, there are other barriers that may affect patient portal adoption, such as lack of reimbursement for telemedicine. These factors were not captured in the HINTS. Second, the HINTS only asked about a limited set of barriers, and it is impossible to tell whether there are other barriers that may be more impactful in hindering patient portal adoption (eg, lack of Spanish language options for the patient portal). Further, the HINTS did not use an implementation framework to select questions related to patient portal barriers. It is possible that other important barriers may have been omitted. The survey questions do, however, capture many of the barriers reported in prior portal studies [38,46-49], suggesting that the questions align well with prior research. Third, the HINTS response rate was around $30 \%$, so it is possible that the findings are not representative of the entire sample owing to nonresponse bias. Finally, the HINTS does not include a measure of multimorbidity (eg, the Charlson comorbidity index), which is positively associated with patient portal adoption. To address this limitation, we included a variable that indicated whether a patient had a chronic condition.

\section{Conclusions}

To our knowledge, this is the first study to assess the prevalence of barriers to patient portal adoption in a nationally representative sample and to discern which patient subgroups are most likely to experience certain barriers. Further research is needed to develop and test implementation strategies that target common barriers to patient portal adoption and tailor implementation and dissemination approaches based on patients' needs and preferences.

\section{Authors' Contributions}

KT developed the research question and study design, conducted the statistical analyses, and drafted the manuscript. AC reviewed the statistical analyses and the manuscript draft and provided feedback. YH reviewed the statistical analyses and the manuscript draft and provided feedback. AA reviewed the statistical analyses and the manuscript draft and provided feedback. CS helped refine aspects of the study design and methodology, reviewed the manuscript draft, and provided feedback.

\section{Conflicts of Interest}

None declared.

\section{Multimedia Appendix 1}

Nonadopter characteristics and no patient portal or internet access.

[DOCX File, 21 KB-Multimedia Appendix 1]

\section{Multimedia Appendix 2}

Nonadopter characteristics and privacy concerns or difficulty logging on. [DOCX File, $21 \mathrm{~KB}-$ Multimedia Appendix 2]

\section{References}

1. Zhou YY, Kanter MH, Wang JJ, Garrido T. Improved quality at Kaiser Permanente through e-mail between physicians and patients. Health Aff (Millwood) 2010 Jul;29(7):1370-1375 [FREE Full text] [doi: 10.1377/hlthaff.2010.0048] [Medline: $\underline{20606190]}$

2. Turner K, Klaman SL, Shea CM. Personal health records for people living with HIV: a review. AIDS Care 2016 Sep;28(9):1181-1187. [doi: 10.1080/09540121.2016.1153594] [Medline: 26917113]

3. McInnes DK, Shimada SL, Midboe AM, Nazi KM, Zhao S, Wu J, et al. Patient Use of Electronic Prescription Refill and Secure Messaging and Its Association With Undetectable HIV Viral Load: A Retrospective Cohort Study. J Med Internet Res 2017 Feb 15;19(2):e34 [FREE Full text] [doi: 10.2196/jmir.6932] [Medline: 28202428]

4. Kruse CS, Bolton K, Freriks G. The effect of patient portals on quality outcomes and its implications to meaningful use: a systematic review. J Med Internet Res 2015;17(2):e44 [FREE Full text] [doi: 10.2196/jmir.3171] [Medline: 25669240] 
5. Graetz I, Huang J, Muelly ER, Fireman B, Hsu J, Reed ME. Association of Mobile Patient Portal Access With Diabetes Medication Adherence and Glycemic Levels Among Adults With Diabetes. JAMA Netw Open 2020 Feb 05;3(2):e1921429 [FREE Full text] [doi: 10.1001/jamanetworkopen.2019.21429] [Medline: 32074289]

6. Zhong X, Park J, Liang M, Shi F, Budd PR, Sprague JL, et al. Characteristics of Patients Using Different Patient Portal Functions and the Impact on Primary Care Service Utilization and Appointment Adherence: Retrospective Observational Study. J Med Internet Res 2020 Feb 25;22(2):e14410 [FREE Full text] [doi: 10.2196/14410] [Medline: 32130124]

7. Zanaboni P, Kummervold PE, Sørensen T, Johansen MA. Patient Use and Experience With Online Access to Electronic Health Records in Norway: Results From an Online Survey. J Med Internet Res 2020 Feb 07;22(2):e16144 [FREE Full text] [doi: 10.2196/16144] [Medline: $\underline{\text { 32031538] }}$

8. Anthony DL, Campos-Castillo C, Lim PS. Who Isn't Using Patient Portals And Why? Evidence And Implications From A National Sample Of US Adults. Health Aff (Millwood) 2018 Dec;37(12):1948-1954. [doi: 10.1377/hlthaff.2018.05117] [Medline: $\underline{30633673}$ ]

9. Jung C, Padman R, Shevchik G, Paone S. Who are portal users vs. early e-Visit adopters? A preliminary analysis. AMIA Annu Symp Proc 2011;2011:1070-1079 [FREE Full text] [Medline: 22195168]

10. Turner K, Hong Y, Yadav S, Huo J, Mainous AG. Patient portal utilization: before and after stage 2 electronic health record meaningful use. J Am Med Inform Assoc 2019 Oct 01;26(10):960-967. [doi: 10.1093/jamia/ocz030] [Medline: 30947331]

11. Graham TA, Ali S, Avdagovska M, Ballermann M. Effects of a Web-Based Patient Portal on Patient Satisfaction and Missed Appointment Rates: Survey Study. J Med Internet Res 2020 May 19;22(5):e17955 [FREE Full text] [doi: 10.2196/17955] [Medline: 32427109]

12. Bailey SC, Wallia A, Wright S, Wismer GA, Infanzon AC, Curtis LM, et al. Electronic Health Record-Based Strategy to Promote Medication Adherence Among Patients With Diabetes: Longitudinal Observational Study. J Med Internet Res 2019 Oct 21;21(10):e13499 [FREE Full text] [doi: 10.2196/13499] [Medline: 31638592 ]

13. Hoogenbosch B, Postma J, de Man-van Ginkel JM, Tiemessen NA, van Delden JJ, van Os-Medendorp H. Use and the Users of a Patient Portal: Cross-Sectional Study. J Med Internet Res 2018 Sep 17;20(9):e262 [FREE Full text] [doi: 10.2196/jmir.9418] [Medline: 30224334]

14. Oh H, Rizo C, Enkin M, Jadad A. What is eHealth (3): a systematic review of published definitions. J Med Internet Res 2005;7(1):e1 [FREE Full text] [doi: 10.2196/jmir.7.1.e1] [Medline: 15829471]

15. Hardiker NR, Grant MJ. Factors that influence public engagement with eHealth: A literature review. Int J Med Inform 2011 Jan;80(1):1-12. [doi: 10.1016/j.ijmedinf.2010.10.017] [Medline: 21112244]

16. Ricciardi L, Mostashari F, Murphy J, Daniel JG, Siminerio EP. A national action plan to support consumer engagement via e-health. Health Aff (Millwood) 2013 Feb;32(2):376-384. [doi: 10.1377/hlthaff.2012.1216] [Medline: 23381531]

17. 2016 Program Requirements. Centers for Medicare and Medicaid Services. 2016. URL: https://www.cms.gov/ Regulations-and-Guidance/Legislation/EHRIncentivePrograms/2016ProgramRequirements.html [accessed 2018-10-30]

18. Lye CT, Forman HP, Daniel JG, Krumholz HM. The 21st Century Cures Act and electronic health records one year later: will patients see the benefits? J Am Med Inform Assoc 2018 Sep 01;25(9):1218-1220. [doi: 10.1093/jamia/ocy065] [Medline: $\underline{30184156]}$

19. Promoting Interoperability. HealthIT. 2019. URL: https://www.healthit.gov/topic/meaningful-use-and-macra/ promoting-interoperability [accessed 2020-09-10]

20. Jhamb M, Cavanaugh KL, Bian A, Chen G, Ikizler TA, Unruh ML, et al. Disparities in Electronic Health Record Patient Portal Use in Nephrology Clinics. Clin J Am Soc Nephrol 2015 Nov 06;10(11):2013-2022 [FREE Full text] [doi: 10.2215/CJN.01640215] [Medline: 26493242]

21. Tarver WL, Menser T, Hesse BW, Johnson TJ, Beckjord E, Ford EW, et al. Growth Dynamics of Patient-Provider Internet Communication: Trend Analysis Using the Health Information National Trends Survey (2003 to 2013). J Med Internet Res 2018 Mar 29;20(3):e109 [FREE Full text] [doi: 10.2196/jmir.7851] [Medline: 29599107]

22. Neinstein A, Thao C, Savage M, Adler-Milstein J. Deploying Patient-Facing Application Programming Interfaces: Thematic Analysis of Health System Experiences. J Med Internet Res 2020 Apr 3;22(4):e16813 [FREE Full text] [doi: 10.2196/16813] [Medline: $\underline{31983680}$ ]

23. Adler-Milstein J, Longhurst C. Assessment of Patient Use of a New Approach to Access Health Record Data Among 12 US Health Systems. JAMA Netw Open 2019 Aug 02;2(8):e199544 [FREE Full text] [doi:

10.1001/jamanetworkopen.2019.9544] [Medline: $\underline{31411708]}$

24. Beckjord EB, Finney RL, Squiers L, Arora NK, Volckmann L, Moser RP, et al. Use of the internet to communicate with health care providers in the United States: estimates from the 2003 and 2005 Health Information National Trends Surveys (HINTS). J Med Internet Res 2007 Jul;9(3):e20 [FREE Full text] [doi: 10.2196/jmir.9.3.e20] [Medline: 17627929]

25. Lustria ML, Smith SA, Hinnant CC. Exploring digital divides: an examination of eHealth technology use in health information seeking, communication and personal health information management in the USA. Health Informatics J 2011 Sep;17(3):224-243. [doi: 10.1177/1460458211414843] [Medline: 21937464]

26. Spooner KK, Salemi JL, Salihu HM, Zoorob RJ. Disparities in perceived patient-provider communication quality in the United States: Trends and correlates. Patient Educ Couns 2016 May;99(5):844-854. [doi: 10.1016/j.pec.2015.12.007] [Medline: 26725930] 
27. Patel V, Barker W, Siminerio E. Disparities in Individuals' Access and Use of Health Information Technology in 2014.

HealthIT. 2016 Feb. URL: https://dashboard.healthit.gov/evaluations/data-briefs/ disparities-individuals-access-use-health-information-technology.php [accessed 2020-09-10]

28. Choi N. Relationship between health service use and health information technology use among older adults: analysis of the US National Health Interview Survey. J Med Internet Res 2011 Apr 20;13(2):e33 [FREE Full text] [doi: 10.2196/jmir.1753] [Medline: 21752784]

29. Yamin CK, Emani S, Williams DH, Lipsitz SR, Karson AS, Wald JS, et al. The digital divide in adoption and use of a personal health record. Arch Intern Med 2011 Mar 28;171(6):568-574. [doi: 10.1001/archinternmed.2011.34] [Medline: 21444847]

30. Greenberg AJ, Haney D, Blake KD, Moser RP, Hesse BW. Differences in Access to and Use of Electronic Personal Health Information Between Rural and Urban Residents in the United States. J Rural Health 2018 Feb;34 Suppl 1:s30-s38. [doi: 10.1111/jrh.12228] [Medline: 28075508]

31. Bhandari N, Shi Y, Jung K. Seeking health information online: does limited healthcare access matter? J Am Med Inform Assoc 2014;21(6):1113-1117 [FREE Full text] [doi: 10.1136/amiajnl-2013-002350] [Medline: 24948558]

32. Lyles CR, Sarkar U, Ralston JD, Adler N, Schillinger D, Moffet HH, et al. Patient-provider communication and trust in relation to use of an online patient portal among diabetes patients: The Diabetes and Aging Study. J Am Med Inform Assoc 2013;20(6):1128-1131 [FREE Full text] [doi: 10.1136/amiajnl-2012-001567] [Medline: 23676243]

33. Goel MS, Brown TL, Williams A, Cooper AJ, Hasnain-Wynia R, Baker DW. Patient reported barriers to enrolling in a patient portal. J Am Med Inform Assoc 2011 Dec;18 Suppl 1:i8-12 [FREE Full text] [doi: 10.1136/amiajnl-2011-000473] [Medline: 22071530]

34. Wildenbos GA, Peute L, Jaspers M. Facilitators and Barriers of Electronic Health Record Patient Portal Adoption by Older Adults: A Literature Study. Stud Health Technol Inform 2017;235:308-312. [Medline: 28423804]

35. Mishuris RG, Stewart M, Fix GM, Marcello T, McInnes DK, Hogan TP, et al. Barriers to patient portal access among veterans receiving home-based primary care: a qualitative study. Health Expect 2014 May 12;18(6):2296-2305. [doi: 10.1111/hex.12199] [Medline: 24816246]

36. Powell KR. Patient-Perceived Facilitators of and Barriers to Electronic Portal Use: A Systematic Review. Comput Inform Nurs 2017 Nov;35(11):565-573. [doi: 10.1097/CIN.0000000000000377] [Medline: 28723832]

37. Ronda MC, Dijkhorst-Oei L, Rutten GE. Reasons and barriers for using a patient portal: survey among patients with diabetes mellitus. J Med Internet Res 2014;16(11):e263 [FREE Full text] [doi: 10.2196/jmir.3457] [Medline: 25424228]

38. Zhao JY, Song B, Anand E, Schwartz D, Panesar M, Jackson GP, et al. Barriers, Facilitators, and Solutions to Optimal Patient Portal and Personal Health Record Use: A Systematic Review of the Literature. AMIA Annu Symp Proc 2017;2017:1913-1922 [FREE Full text] [Medline: 29854263]

39. Sakaguchi-Tang DK, Bosold AL, Choi YK, Turner AM. Patient Portal Use and Experience Among Older Adults: Systematic Review. JMIR Med Inform 2017 Oct 16;5(4):e38 [FREE Full text] [doi: 10.2196/medinform.8092] [Medline: 29038093]

40. Sadasivaiah S, Lyles CR, Kiyoi S, Wong P, Ratanawongsa N. Disparities in Patient-Reported Interest in Web-Based Patient Portals: Survey at an Urban Academic Safety-Net Hospital. J Med Internet Res 2019 Mar 26;21(3):e11421 [FREE Full text] [doi: 10.2196/11421] [Medline: 30912747]

41. Tieu L, Sarkar U, Schillinger D, Ralston JD, Ratanawongsa N, Pasick R, et al. Barriers and Facilitators to Online Portal Use Among Patients and Caregivers in a Safety Net Health Care System: A Qualitative Study. J Med Internet Res 2015;17(12):e275 [FREE Full text] [doi: 10.2196/jmir.4847] [Medline: 26681155]

42. Irizarry T, Shoemake J, Nilsen ML, Czaja S, Beach S, DeVito DA. Patient Portals as a Tool for Health Care Engagement: A Mixed-Method Study of Older Adults With Varying Levels of Health Literacy and Prior Patient Portal Use. J Med Internet Res 2017 Mar 30;19(3):e99 [FREE Full text] [doi: 10.2196/jmir.7099] [Medline: 28360022]

43. Kim S, Fadem S. Communication matters: Exploring older adults' current use of patient portals. Int J Med Inform 2018 Dec;120:126-136. [doi: 10.1016/j.ijmedinf.2018.10.004] [Medline: 30409337]

44. Health Information National Trends Survey 5 (HINTS 5) Cycle 3 Methodology Report. National Cancer Institute. 2019 Aug. URL: https://hints.cancer.gov/docs/Instruments/HINTS5 Cycle3 MethodologyReport.pdf [accessed 2020-09-10]

45. von Elm E, Altman DG, Egger M, Pocock SJ, Gøtzsche PC, Vandenbroucke JP. The Strengthening the Reporting of Observational Studies in Epidemiology (STROBE) Statement: Guidelines for reporting observational studies. International Journal of Surgery 2014 Dec;12(12):1495-1499 [FREE Full text] [doi: 10.1016/j.ijsu.2014.07.013] [Medline: 25046131]

46. Eden KB, Totten AM, Kassakian SZ, Gorman PN, McDonagh MS, Devine B, et al. Barriers and facilitators to exchanging health information: a systematic review. Int J Med Inform 2016 Apr;88:44-51 [FREE Full text] [doi:

10.1016/j.ijmedinf.2016.01.004] [Medline: 26878761]

47. Irizarry T, DeVito DA, Curran CR. Patient Portals and Patient Engagement: A State of the Science Review. J Med Internet Res 2015;17(6):e148 [FREE Full text] [doi: 10.2196/jmir.4255] [Medline: 26104044]

48. Lockwood MB, Dunn-Lopez K, Pauls H, Burke L, Shah SD, Saunders MA. If you build it, they may not come: modifiable barriers to patient portal use among pre- and post-kidney transplant patients. JAMIA Open 2018 Oct;1(2):255-264 [FREE Full text] [doi: 10.1093/jamiaopen/ooy024] [Medline: 31984337] 
49. Lyles CR, Allen JY, Poole D, Tieu L, Kanter MH, Garrido T. "I Want to Keep the Personal Relationship With My Doctor": Understanding Barriers to Portal Use among African Americans and Latinos. J Med Internet Res 2016 Oct 03;18(10):e263 [FREE Full text] [doi: 10.2196/jmir.5910] [Medline: 27697748]

50. Lomas J. Diffusion, Dissemination, and Implementation: Who Should Do What? Ann NY Acad Sci 1993 Dec 31;703:226-235. [doi: 10.1111/j.1749-6632.1993.tb26351.x] [Medline: $\underline{\text { 8192299] }}$

51. Bose-Brill S, Feeney M, Prater L, Miles L, Corbett A, Koesters S. Validation of a Novel Electronic Health Record Patient Portal Advance Care Planning Delivery System. J Med Internet Res 2018 Jun 26;20(6):e208 [FREE Full text] [doi: 10.2196/jmir.9203] [Medline: 29945860]

52. Groen WG, Kuijpers W, Oldenburg HS, Wouters MW, Aaronson NK, van Harten WH. Supporting Lung Cancer Patients With an Interactive Patient Portal: Feasibility Study. JMIR Cancer 2017 Aug 08;3(2):e10 [FREE Full text] [doi: 10.2196/cancer.7443] [Medline: 28790025]

53. Li J, Yazdany J, Trupin L, Izadi Z, Gianfrancesco M, Goglin S, et al. Capturing a Patient-Reported Measure of Physical Function Through an Online Electronic Health Record Patient Portal in an Ambulatory Clinic: Implementation Study. JMIR Med Inform 2018 May 09;6(2):e31 [FREE Full text] [doi: 10.2196/medinform.8687] [Medline: 29743158]

54. Price-Haywood EG, Harden-Barrios J, Ulep R, Luo Q. eHealth Literacy: Patient Engagement in Identifying Strategies to Encourage Use of Patient Portals Among Older Adults. Population Health Management 2017 Dec;20(6):486-494. [doi: 10.1089/pop.2016.0164] [Medline: 28384076]

55. Martinez W, Threatt AL, Rosenbloom ST, Wallston KA, Hickson GB, Elasy TA. A Patient-Facing Diabetes Dashboard Embedded in a Patient Web Portal: Design Sprint and Usability Testing. JMIR Hum Factors 2018 Sep 24;5(3):e26 [FREE Full text] [doi: 10.2196/humanfactors.9569] [Medline: $\underline{30249579]}$

56. Nazi KM, Turvey CL, Klein DM, Hogan TP. A Decade of Veteran Voices: Examining Patient Portal Enhancements Through the Lens of User-Centered Design. J Med Internet Res 2018 Jul 10;20(7):e10413 [FREE Full text] [doi: 10.2196/10413] [Medline: 29991468]

57. Maher M, Kaziunas E, Ackerman M, Derry H, Forringer R, Miller K, et al. User-Centered Design Groups to Engage Patients and Caregivers with a Personalized Health Information Technology Tool. Biol Blood Marrow Transplant 2016 Feb;22(2):349-358 [FREE Full text] [doi: 10.1016/j.bbmt.2015.08.032] [Medline: 26343948]

58. Garrido T, Kanter M, Meng D, Turley M, Wang J, Sue V, et al. Race/ethnicity, personal health record access, and quality of care. Am J Manag Care 2015 Feb;21(2):e103-e113 [FREE Full text] [Medline: 25880485]

59. Wallace LS, Angier H, Huguet N, Gaudino JA, Krist A, Dearing M, et al. Patterns of Electronic Portal Use among Vulnerable Patients in a Nationwide Practice-based Research Network: From the OCHIN Practice-based Research Network (PBRN). J Am Board Fam Med 2016 Oct;29(5):592-603 [FREE Full text] [doi: 10.3122/jabfm.2016.05.160046] [Medline: 27613792]

60. Arcia A. Time to Push: Use of Gestational Age in the Electronic Health Record to Support Delivery of Relevant Prenatal Education Content. EGEMS (Wash DC) 2017 Apr 20;5(2):5 [FREE Full text] [doi: 10.13063/2327-9214.1281] [Medline: 29881749]

61. McAlearney AS, Sieck CJ, Hefner JL, Aldrich AM, Walker DM, Rizer MK, et al. High Touch and High Tech (HT2) Proposal: Transforming Patient Engagement Throughout the Continuum of Care by Engaging Patients with Portal Technology at the Bedside. JMIR Res Protoc 2016 Nov 29;5(4):e221 [FREE Full text] [doi: 10.2196/resprot.6355] [Medline: 27899338]

62. Ramsey A, Lanzo E, Huston-Paterson H, Tomaszewski K, Trent M. Increasing Patient Portal Usage: Preliminary Outcomes From the MyChart Genius Project. J Adolesc Health 2018 Jan;62(1):29-35 [FREE Full text] [doi:

10.1016/j.jadohealth.2017.08.029] [Medline: 29169768]

63. McCleary NJ, Greenberg TL, Barysauskas CM, Guerette EJ, Hassan M, Jacobson JO, et al. Oncology Patient Portal Enrollment at a Comprehensive Cancer Center: A Quality Improvement Initiative. J Oncol Pract 2018 Aug; 14(8):e451-e461. [doi: 10.1200/JOP.17.00008] [Medline: 30096276]

64. Ennis L, Robotham D, Denis M, Pandit N, Newton D, Rose D, et al. Collaborative development of an electronic Personal Health Record for people with severe and enduring mental health problems. BMC Psychiatry 2014;14(1):305 [FREE Full text] [doi: 10.1186/s12888-014-0305-9] [Medline: 25403285]

65. Ancker JS, Witteman HO, Hafeez B, Provencher T, Van DG, Wei E. "You Get Reminded You're a Sick Person": Personal Data Tracking and Patients With Multiple Chronic Conditions. J Med Internet Res 2015;17(8):e202 [FREE Full text] [doi: 10.2196/jmir.4209] [Medline: 26290186]

66. Fix GM, Hogan TP, Amante DJ, McInnes DK, Nazi KM, Simon SR. Encouraging Patient Portal Use in the Patient-Centered Medical Home: Three Stakeholder Perspectives. J Med Internet Res 2016 Nov 22;18(11):e308 [FREE Full text] [doi: 10.2196/jmir.6488] [Medline: 27876686]

67. Gordon NP, Hornbrook MC. Differences in Access to and Preferences for Using Patient Portals and Other eHealth Technologies Based on Race, Ethnicity, and Age: A Database and Survey Study of Seniors in a Large Health Plan. J Med Internet Res 2016 Mar 04;18(3):e50 [FREE Full text] [doi: 10.2196/jmir.5105] [Medline: 26944212]

68. Zickuhr K, Smith A. Home Broadband 2013. Pew Research Center. 2013 Aug. URL: https://www.pewresearch.org/internet/ 2013/08/26/home-broadband-2013/ [accessed 2020-09-10]

69. Xie B. Effects of an eHealth literacy intervention for older adults. J Med Internet Res 2011 Nov;13(4):e90 [FREE Full text] [doi: 10.2196/jmir.1880] [Medline: 22052161] 
70. Xie B, Bugg JM. Public library computer training for older adults to access high-quality Internet health information. Libr Inf Sci Res 2009 Sep 1;31(3):155 [FREE Full text] [doi: 10.1016/j.lisr.2009.03.004] [Medline: 20161649]

71. Watkins I, Xie B. eHealth literacy interventions for older adults: a systematic review of the literature. J Med Internet Res 2014;16(11):e225 [FREE Full text] [doi: 10.2196/jmir.3318] [Medline: 25386719]

72. Smith A. Older Adults and Technology Use. Pew Research Center. 2014 Apr. URL: https://www.pewresearch.org/internet/ 2014/04/03/older-adults-and-technology-use/ [accessed 2020-09-10]

73. Sarkar U, Bates DW. Care Partners and Online Patient Portals. JAMA 2014 Jan 22;311(4):357-358. [doi: 10.1001/jama.2013.285825] [Medline: 24394945]

74. Wolff JL, Berger A, Clarke D, Green JA, Stametz R, Yule C, et al. Patients, care partners, and shared access to the patient portal: online practices at an integrated health system. J Am Med Inform Assoc 2016 Nov;23(6):1150-1158. [doi: 10.1093/jamia/ocw025] [Medline: 27026614]

75. Weis A, Pohlmann S, Poss-Doering R, Strauss B, Ullrich C, Hofmann H, et al. Caregivers' role in using a personal electronic health record: a qualitative study of cancer patients and caregivers in Germany. BMC Med Inform Decis Mak 2020 Jul 13;20(1):158 [FREE Full text] [doi: 10.1186/s12911-020-01172-4] [Medline: $\underline{\text { 32660600] }}$

\section{Abbreviations \\ EHR: electronic health record \\ HINTS: Health Information National Trends Survey \\ NCI: National Cancer Institute \\ OR: odds ratio}

Edited by G Eysenbach; submitted 24.03.20; peer-reviewed by T Garrido, M Barwick; comments to author 18.07.20; revised version
received 22.07.20; accepted 16.08.20; published 17.09.20
Please cite as:
Turner K, Clary A, Hong YR, Alishahi Tabriz A, Shea CM
Patient Portal Barriers and Group Differences: Cross-Sectional National Survey Study
J Med Internet Res 2020;22(9):e18870
URL: $\underline{\text { http://www.jmir.org/2020/9/e18870/ }}$
doi: $\underline{10.2196 / 18870}$
PMID: $\underline{32940620}$

(CKea Turner, Alecia Clary, Young-Rock Hong, Amir Alishahi Tabriz, Christopher M Shea. Originally published in the Journal of Medical Internet Research (http://www.jmir.org), 17.09.2020. This is an open-access article distributed under the terms of the Creative Commons Attribution License (https://creativecommons.org/licenses/by/4.0/), which permits unrestricted use, distribution, and reproduction in any medium, provided the original work, first published in the Journal of Medical Internet Research, is properly cited. The complete bibliographic information, a link to the original publication on http://www.jmir.org/, as well as this copyright and license information must be included. 